\title{
EVALUATION OF EFFECTIVENESS OF SURGICAL CORRECTION OF HIGH DEGREE CAROTID ARTERY STENOSIS VIA DUPLEX SONOGRAPHY
}

\author{
Mazur S.G. ${ }^{1}$, Kostyuk M.R. ${ }^{2}$, Dikan I.N. ${ }^{1},{ }^{*}$ Kuznetsov V.V. ${ }^{3}$ \\ ${ }^{1}$ Institute of Nuclear Medicine and Radiodiagnostics, NAMS, Ukraine, \\ ${ }^{2}$ Neurosurgery Institute named after A.P.Romodanov, NAMS, Ukraine, \\ ${ }^{3}$ Herontology Institute named after D.F. Chebotarev, NAMS, Ukraine
}

Key words: carotid artery, duplex sonography, carotid stenosis.

$\mathbf{S}^{\mathrm{t}}$ troke is at the third place after cardiologic disorders and cancer among causes of death in economically developed countries $[1,2]$. In Ukraine, cerebrovascular mortality occupies second place among causes of overall mortality [3], whereas adult population disability is often associated with sequelae of previous acute cerebrovascular disorder (ACVD). During recent years, incidence rate of stroke in the country has been exceeding 100000 cases per year.

In accordance with epidemiologic data, in vast majority of cases (70-80\%) strokes are of ischemic origin, which in $25 \%$ cases is caused by atherosclerotic changes in extracranial segments of carotid arteries (CA) $[4,5,6]$.

Based on established indications, surgical treatment methods have indisputable advantages over medicinal prevention of ischemic CVD upon atherosclerotic stenosis of main cerebral arteries (MCA) of high degree. Operative remodeling of arterial lumen allows elimination of source of thromboembolism (microthrombs, atheromatous plaque fragments) in brain arteries, prevents development of occlusion in stenosis site (thromb formation, dissection, hemorrhage into atherosclerotic plaque) and normalizes blood circulation in relevant vascularization area. Technologic advances during the last decade contributed to application of endovascular intervention methods in clinical practice, which significantly broadens capabilities of surgical correction of stenotic damages in MCA.

Currently, Carotid Endarterectomy (CEA) remains as the most effective method (the so-called "Gold Standard) of treatment of extracranial atherosclerotic stenosis of $\mathrm{CA}$ in comparison with both medicinal treatment and endovascular stent- ing $[7,8,9,10]$. At the beginning of 2000's introduction of endovascular techniques of carotid angioplasty and stenting (CAS) for surgical treatment of stenosis of CA had limitations; as a rule, patients who underwent CEA had higher risk of complications. However, majority of recent randomized trials have demonstrated comparability of this miniinvasive procedure to conventional open surgery in terms of effectiveness and safety. Expert opinions are different regarding conclusions of these studies, which warrant further investigation to determine the most effective treatment approach for effective surgical prevention of stroke depending on the specificities of atherosclerotic lesions in CA, clinical course of the disease, and other factors [11].

Basis for indications for surgical treatment of CA stenosis depends on exact determination of location and morphologic features of damage, evaluation of patency of mixed MCA, circulation parameters in damaged artery and intracranial parts of cerebral arteries. State-of-the-art noninvasive diagnostic tools (Ultrasonic Dopplerography, magnetic-resonance and computer tomographic angiography) are capable of accurately determining patients, whom reconstructive surgical intervention may be indicated for lowering ischemic stroke risk. Ultrasonic duplex scanning (USDS), which ensures bias-free diagnostic criteria for determining changes in vascular patency prior to and following surgical intervention has become more widely used in recent years.

Purpose of Study: evaluate changes in carotid artery patency and parameters of cerebral hemodynamics with use of duplex sonography following surgical correction of high degree carotid artery stenosis.

\footnotetext{
*e-mail: stroke_kiev@mail.ru
} 
Materials and Methods. 62 patients (56 males, 6 females) at the age of 43-84 (mean age 60.8 55.6 years) with carotid artery stenosis, who underwent angioplastic surgery and stenting with the purpose of preventing cerebrovascular disorders (CVD) and improving cerebral hemoperfusion were evaluated. In 6 cases bilateral stenosis was corrected in both sides one at a time, whereas in 5 cases one of the carotid arteries was stent grafted, followed by a CEA in the opposite one. Hense, 62 patients had 73 surgical operations performed on them in total - 68 stentings and 5 CEAs.

All patients had DS in accordance with established protocol three times based on the following timeline: within 1 week prior to surgery, within first week and 6-8 month after surgery.

Degree of stenosis in extracranial section of carotid arteries exceeded $60 \%$ in all patients. In 60 cases, indication for endovascular surgery was increased risk of performing CEA and remaining 8 patients insisted on performing a mini-invasive intervention. In bilateral ICA stenosis of high degree, where CEA was planned, patency of contralateral artery was pre-restored via stenting. Such approach had a purpose of improving collateral blood circulation for safe blockage of ICA during removal of atherosclerotic plaque.

Clinical course of the disease, neurologic and somatic status of patients were evaluated prior to surgical intervention. Presence of changes in brain structures was identified based on the results of computer- or magnetic-resonance tomography. Duplex sonography was performed using ultrasound diagnostic system named SONOLINE ELEGRA (Siemens, Germany) using a transmitter with 7.5 and $2.5 \mathrm{MHz}$ frequency. Location specifics of arteries, condition of vascular wall, and structure and characteristics of atheromatous plaques were evaluated, as well as degree of stenosis and carotid coefficient were calculated during evaluation process. Degree of stenosis was estimated based on diameter in longitudinal and transversal projections and based on area in transversal projection. Carotid coefficient was calculated based on ratio of peak systolic velocity in maximum occlusion site of internal carotid artery to relevant parameter in common carotid artery. Selective cerebral angiography (CCA) and endovascular intervention were performed using angiographic equipment named Neurostar-Top and Axiom-Artis (Siemens, Germany). If high degree stenosis of CA is observed in ultrasound evaluation and it is determined that surgical correction of pathology is relevant, all patients had selective cerebral angiography performed on them for making a final decision favoring operative treatment. In individual cases angiographic investigations were followed by stent grafting, if endovascular intervention had been planned initially. Surgical procedure met commonly-accepted standards and in all cases self-expanding carotid stents were used. In 58 cases anti-embolic protection system was used. CEA was performed using traditional techniques, without application of intralaminar bypass and vascular patch was not implanted in arteriotomy site. Atherosclerotic plaque was removed in circular manner through linear artery incision and restoration of vascular wall was conducted using continuous suture technique.

Obtained results were calculated in an integrated system for comprehensive data analysis using Windows STATISTICA -6.0 Stat Soft Inc., USA.

\section{Study Results}

Evaluating clinical manifestations of stenotic damage in carotid arteries in examined patients, it should be noted that in $28.8 \%$ cases (18 patients) the disease had an asymptomatic course, in 14.4\% (9 patients) disease manifestation occurred in form of transient ischemic attach (TIA), the so-called minor or non-disabling stroke was observed in 23 patients $(36.8 \%), 11$ patients $(17.7 \%)$ presented with disabling stroke, and one patient (1.6\%) had stroke in Vertebrobasilar Basin.

As a result of comprehensive clinical and neurologic evaluation of patients, structure of concurrent disorders was determined (Table 1). The most diagnosed diseases complicating course of main disease were: hypertension, ischemic heart disease, post-infarction myocardiosclerosis, cardiac rhytm disorders, chronic obstructive diseases of bronchi and lungs, and diabetes. 
Concurrent Diseases in Surgically Treated Patients

Table 1.

\begin{tabular}{|l|l|l|}
\hline Hypertension & 51 & $(82.3 \%)$ \\
\hline Postinfarction Myocardiosclerosis & 10 & $(16.7 \%)$ \\
\hline Ischemic Heart Disease & 48 & $(77.8 \%)$ \\
\hline Arhytmias & 11 & $(17.7 \%)$ \\
\hline Heart Valve Disease (planned heart surgery with use of extracorporeal blood circulation) & 5 & $(8.1 \%)$ \\
\hline Obliterating disorders of lower extremity arteries & 5 & $(8.1 \%)$ \\
\hline Diabetes & 15 & $(24.2 \%)$ \\
\hline Chronic Obstructive Bronchopulmonary Disease & 12 & $(19.4 \%)$ \\
\hline Obesity & 10 & $(16.7 \%)$ \\
\hline
\end{tabular}

Patient distribution based on degree of stenosis in ICA was as follows: stenosis occupying less than $70 \%$ of vascular diameter - 18 patients (29.6\%); 70-90\% stenosis - 30 (48.1\%); critical stenosis, occluding over $90 \%$ of the diameter of artery - 14 patients (22.2\%) (Fig. 1).
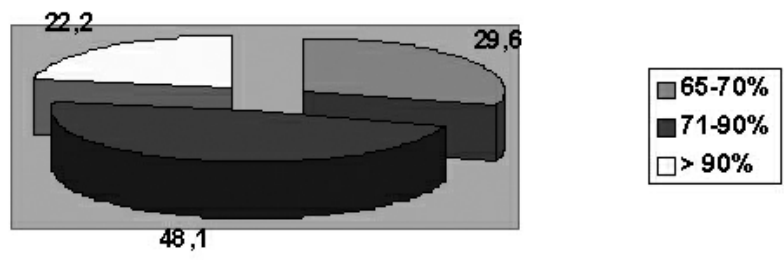

Fig.1. Patient distribution based on degree of stenosis in carotid arteries
It is worthwhile to note that, majority of patients had combined damage in MCA, which de-compensated collateral blood circulation and served as an additional factor necessitating operative correction of stenosis. Combined involvements of mixed cerebral arteries were observed in 40 patients $(64.5 \%)$. Patient distribution based on features and severity of stenosis is presented below in Table 2.

\section{Occlusion/stenosis of Mixed Cerebral Basins}

\begin{tabular}{|l|l|l|}
\hline Occlusion of contralateral ICA & 18 & $(29.0 \%)$ \\
\hline$>70 \%$ stenosis of contralateral ICA & 10 & $(16.7 \%)$ \\
\hline - extracranial & -6 & \\
\hline - intracranial & -4 & \\
\hline Detachment of collateral blood circulation through arterial circle of brain basis & 3 & $(4.8 \%)$ \\
\hline Occlusion/atresia of single vertebral artery & 6 & $(9.7 \%)$ \\
\hline Tandem stenosis of ipsilateral ICA & 3 & $(4.8 \%)$ \\
\hline
\end{tabular}

Data available from previous studies [12] regarding existence of high correlation between the results of USDS in longitudinal projection and CAG method (in terms of degree of stenosis per arterial diameter) demonstrate high informativity of USDS in diagnosis of carotid artery stenosis ( $\mathrm{r}=$ +0.72 ). USDS allows not only to determine degree of stenosis, but to assess hemodynamic parameters as well both prior to and following surgical correction of stenosis, which may serve as an objective criterion in evaluating effectiveness of surgery both right after the operation and in long-term.

In all cases following CAS vascular patency was sufficiently restored in stenosis site and residual narrowing up to $15 \%$ was observed in 11 patients $(17.7 \%)$. Stenosis of ICA, degree of which was
$76.5 \pm 1.9 \%$ in CAG and $77.2 \pm 1.5 \%$ in USDS prior to surgery, was almost completely eliminated thanks to surgical intervention and degree of residual stenosis right after surgery was $3.8 \pm 1.4 \%$ $(p<0.05)$ in $C A G$ and $10.6 \pm 1.8 \%(p<0.05)$ in USDS and no increase was noted 6 months after surgery, being $13.3 \pm 2.4 \%(p<0.05)$ in USDS. Taking into account the absence of re-stenosis symptoms, conducting CAG for evaluating ICA patency in early post-surgical period was considered inappropriate. Level of carotid artery patency based on CAG and USDS findings prior to and following CAS surgery, as well as effectiveness of combined surgical treatment of high degree bilateral stenosis of internal carotid arteries based on USDS findings are presented in Figures 2, 3, and 4. 


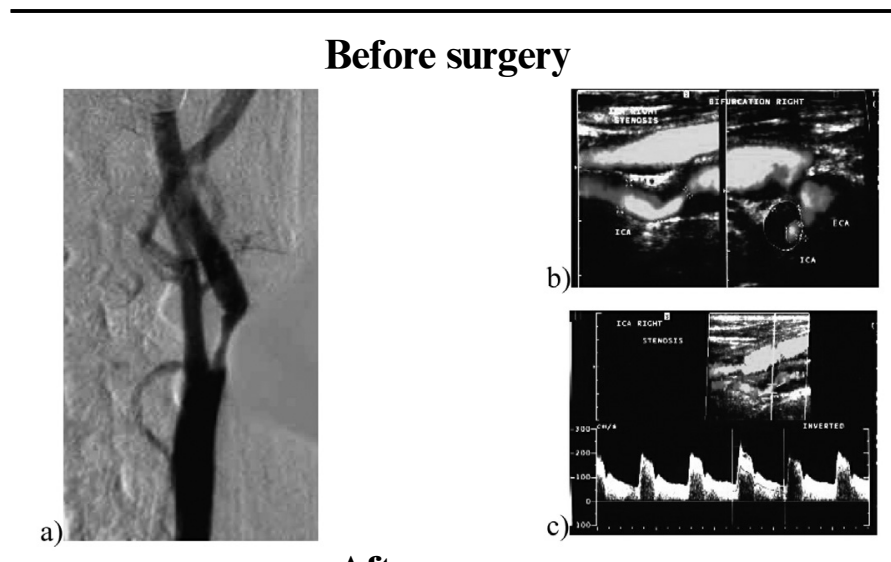

After surgery

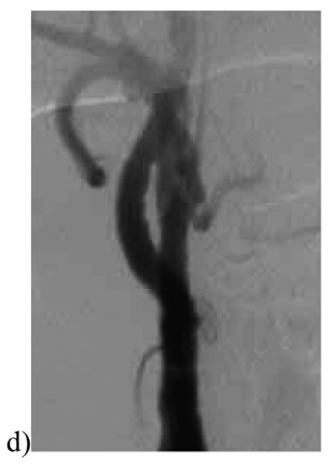

Fig. 2: Patient B, 84 years old. Recurrent TIA in right carotid basin. High degree stenosis of right ICA based on CAG (a) - 73\%, based on USDS (b) - 68\%; c) presence of stenosis-related acceleration in occlusion site. Elimination of stenosis after CAS surgery: $\mathrm{d}$ ) based on CAG findings; e), f) - based on USDS findings.

\section{Before surgery}
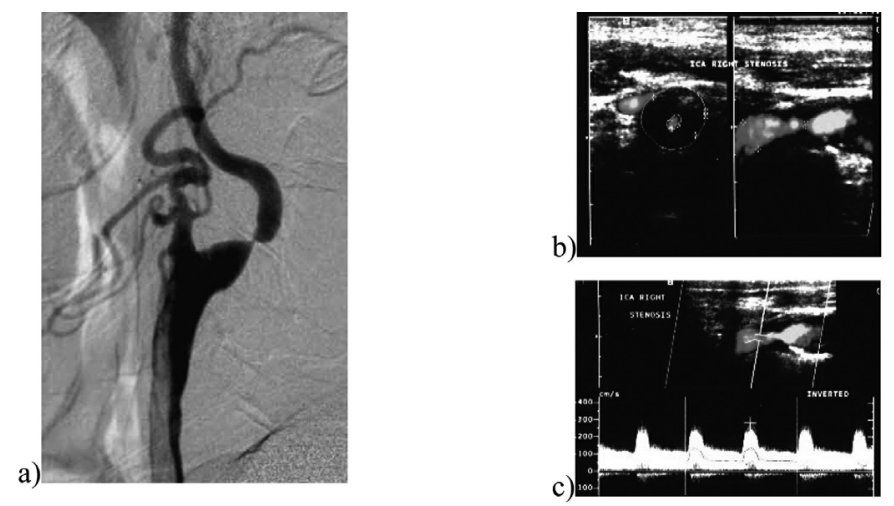

After surgery

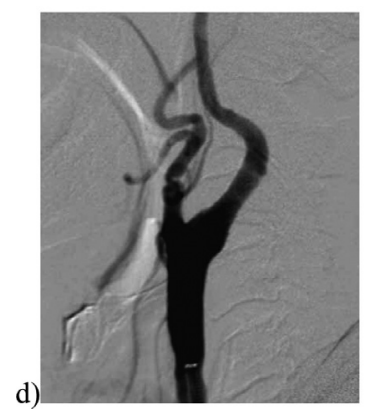

Fig. 3: Patient C, 66 years. Progressive encephalopathy. High degree stenosis of right ICA based on CAG findings (a) - 91\%, based on USDS findings (b) - $85 \%$; c) presence of stenosis-related acceleration in occlusion site. Elimination of stenosis after CAS surgery: d) based on CAG findings; e) based on USDS findings.

\section{Before surgery}
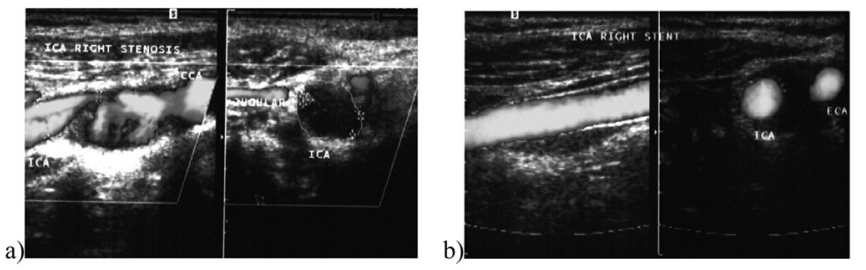

\section{After surgery}
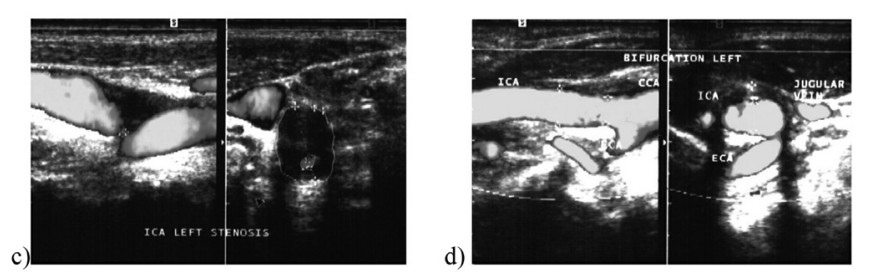

Fig. 4: Patient D, 59 years. High degree bilateral stenosis of carotid arteries: right ICA - 94\%, left ICA - 90\%. Effectiveness of combined surgical treatment based on USDS findings, elimination of stenosis of right ICA using CAS technique $(a, b)$, elimination of stenosis of left ICA using CEA (c, d).

Apart from removal of stenosis in ICA, surgical intervention contributed to improvement of hemodynamic parameters in stent site: stenosis-related acceleration of blood flow disappeared, carotid coefficient returned to norm range. Change patterns in mean hemodynamic values due to surgical treatment are provided in Table 3.

It should be noted, that measured values significantly changed due to surgery and these changes were sustained in early period after stent grafting. Thus, stenosis-related acceleration of blood flow, mean value of which was $263.0 \pm 14 \mathrm{~cm} / \mathrm{sec}$ in before surgery in examined patients was eliminated after surgery, as the average blood velocity in stent site was $57.2 \pm 2.2 \mathrm{~cm} / \mathrm{sec}(\mathrm{p}<0.05)$ right after surgery and $60.9 \pm 3.8(\mathrm{p}<0.05) 6$ month after surgery. Carotid coefficient, mean value of which was $7.8 \pm 0.6$ before surgery demonstrated significant decrease to $1.5 \pm 0.1(p<0.05)$ right after surgery and remained on about the same level in early post- 
Change in hemodynamic parameters and degree of stenosis in ICA due to surgical treatment

Table 3

\begin{tabular}{|l|l|l|l|}
\hline Value / observation time & Before surgery & After surgery & $6-8$ months after surgery \\
\hline Peak systolic volume, cm/sec & $263.0 \pm 14$ & $57.2 \pm 2.2^{*}$ & $60.9 \pm 3.8^{*}$ \\
\hline Carotid coefficient & $7.8 \pm 0.6$ & $1.5 \pm 0.1^{*}$ & $1.7 \pm 0.2^{*}$ \\
\hline Degree of stenosis based on CAG findings, $\%$ & $76.5 \pm 1.9 \%$ & $3.8 \pm 1.4^{*}$ & Not performed \\
\hline Degree of stenosis based on USDS findings, $\%$ & $77.2 \pm 1.5 \%$ & $10.6 \pm 1.8^{*}$ & $13.3 \pm 2.4^{*} \%^{*}$ \\
\hline
\end{tabular}

Note: ${ }^{*} \mathrm{p}<0.05$ value shows statistically significant difference between parameters before and after surgery.

surgical period, being $1.7 \pm 0.2(\mathrm{p}<0.05)$.

High degree stenosis of one of the ICAs in combination with occlusion of contralateral ICA significantly increases risk of ischemic stroke, since chronic cerebral circulation insufficiency develops in such situations, with significant burden on compensation mechanisms.

Taking into account that, majority of operated patients consisted of those who we considered appropriate for separate examination for hemody- namic parameters.

Improvement was observed in intracranial hemodynamic values was observed due to surgery, evidenced by positive changes in linear blood velocity (LBV) values in medial cerebral artery (MCA) on the side of stenting and on opposite side.

Trends in LBV values in MCA on stented and the opposite side in patients with and without ICA occlusion are provided in Table 5.

Table 5

Trends in LBV values in MCA on stented and the opposite side in patients with and without ICA occlusion

\begin{tabular}{|c|c|c|c|c|c|c|}
\hline Time of & Before surgery & & 4-7 days after surg & sery & 6 months after sur & gery \\
\hline 8. & $\begin{array}{l}\text { Occlusion of con- } \\
\text { tralateral ICA }\end{array}$ & No occlusion & $\begin{array}{l}\text { Occlusion of con- } \\
\text { tralateral ICA }\end{array}$ & No occlusion & $\begin{array}{l}\text { Occlusion of con- } \\
\text { tralateral ICA }\end{array}$ & No occlusion \\
\hline On stented side & $102.64 \pm 3.81^{*}$ & $88.63 \pm 4.45^{*}$ & $109.19 \pm 4.34 *$ & $106.25 \pm 3.82$ & $110.1 \pm 2.77$ & $109.45 \pm 7.08$ \\
\hline $\begin{array}{l}\text { On contralateral } \\
\text { side }\end{array}$ & $83.68 \pm 6.48 *$ & $93.10 \pm 4.49 *$ & $85.66 \pm 4.95^{*}$ & $102.92 \pm 4.63^{*} \#$ & $75.97 \pm 11.02^{*}$ & $103.0 \pm 4.30^{* \#}$ \\
\hline
\end{tabular}

Note: $* \mathrm{p}<0.05$ value means statistically significant difference versus control group

$\# \mathrm{p}<0.05$ value means statistically significant difference in both groups (with and w/o occlusion of contralateral ICA

Findings demonstrate that all patients had statistically significant difference in LBV values in MCA compared to placebo both on the side of stenosis and on contralateral side before surgery. Thus, before surgery LBV in MCA on the side of stenosis in patients with occlusion of contralateral ICA was $102.64 \pm 3.81 \mathrm{~cm} / \mathrm{sec}$ and on the opposite side it was $83.68 \pm 6.48 \mathrm{~cm} / \mathrm{sec}$, however both parameters were significantly lower than respective value in control group $(121.7 \pm 8.59 \mathrm{~cm} / \mathrm{sec})$ $(\mathrm{p}<0.05)$. Slight increase of these values was observed after surgery; however, such change was not statistically significant compared to pre-operation values ( $p>0.05)$. In the group of patients without occlusion of contralateral ICA, changes were more evident in intracranial parameters, as the LBV in MCA was $88.63 \pm 4.45 \mathrm{~cm} / \mathrm{sec}$ on the side of stenosis of ICA before surgery and $93.103 \pm 4.49$ $\mathrm{cm} / \mathrm{sec}$ on the opposite side, where both values were significantly lower compared to control group $(\mathrm{p}<0.05)$. Improvement of these parameters up to $106.25 \pm 3.82 \mathrm{~cm} / \mathrm{sec}$ on the side of stenting and up to $102.92 \pm 4.63 \mathrm{~cm} / \mathrm{sec}$ on the opposite side occurred after surgery (4-7 days). Although, they did not reach the same level with those of control group patients, these differences already lost their statistical significance $(\mathrm{p}>0.05)$. In early postoperative period they remained approximately on the same level, being $109.45 \pm 7.08$ and up to $103.00 \pm 4.30 \mathrm{~cm} / \mathrm{sec}$ on the side of stent and on the opposite side, respectively and demonstrated no statistically significant difference versus control group values ( $p>0.05)$.

Based on above-mentioned findings, it may be 
stated that restoration of patency in carotid arteries using CAS method in combination with CEA when necessary is an effective surgical approach, characterized with minimal risk of postoperative complications and sustainable retention of vascular patency.

\section{Conclusions}

1. significant hemodynamic changes, such as initiation of stenosis-related acceleration of blood flow and increase in carotid coefficient are observed in patients with occlusion/stenosis of carotid arteries requiring surgical intervention.

2. Surgical treatment options (CAS, if required in combination with CEA) improve hemodynamic parameters: they restore arterial patency in lesion

\section{REFERENCES}

1. Feigin VL, Lawes CM, Bennett DA, Barker-Collo SL, Parag V. Worldwide stroke incidence and early case fatality reported in 56 population-based studies: a systematic review // The Lancet Neurology. - 2009.- P. 355 - 369.

2. Matchar DB: Cost of stroke. Stroke Clin Update 2002; 5: 9-12.

3. Міщенко Т.С. Епідеміологія церебро-васкулярних захворювань в Україні у 2007 році. // Судинні захворювання головного мозку. - 2008. - №2. - С.3-7.

4. Sacco RL, Roberts JK, Boden-Albala, et al. Race-ethnicity and determinants of carotid atherosclerosis in a multiethnic population. The Northern Manhattan Stroke Study. Stroke 1997; 28: 929-935.

5. Sacco RL, Adams R, Albers G, et al. Guidelines for prevention of stroke in patients with ischemic stroke or transient ischemic attack: A statement for healthcare professionals from the American heart association / American stroke association council on stroke: Co-sponsored by the council on cardiovascular radiology and intervention: The American academy of neurology affirms the value of this guideline. Stroke 2006; 37: 577-617.

6. Corso GBE, Giardini G. Community-base study of stroke incidence in the Aosta Valley, Italy. CARe-Cerebrovascular Aosta Registry: years 2004-2005. Neuroepidemiology 2009; 32: 186-195.

7. European Carotid Surgery Trialists Collaborative Group. site, eliminate stenosis-related acceleration of blood-flow, and normalize carotid coefficient.

3. Duplex sonography (USDS) is a highlyinformative tool for diagnosing stenosis of carotid arteries, evaluating condition of stent and ICA patency after surgery, which characterizes effectiveness of surgical intervention.

4. Characteristic positive hemodynamic changes are observed in carotid and vertebrobasilar basins in patients with occlusion of contralateral ICA after removal of high-degree stenosis of ICA, which reflect compensatory and adaptive mechanisms of autoregulation of cerebral blood circulation.

Randomized trial of endarterectomy for recently symptomatic carotid stenosis: final result of the MRC European Carotid Surgery Trial (ESCT). Lancet 1998; 351: 1379-1387. 8. Rotwell PM, Eliasziw M, Gutnikov SA, et al. Carotid Endarterectomy Trialists Collaboration. Endarterectomy for symptomatic carotid stenosis in relation to clinical subgroups and timing of surgery. Lancet. 2004; 363: 915-924.

9. International Carotid Stenting Study investigators. Carotid artery stenting compared with endarterectomy in patients with symptomatic carotid stenosis (International Carotid Stenting Study): an interim analysis of a randomised controlled trial. The Lancet 2010; 375: 985 - 997.

10. Goldstein LB, Hasselblad V, Matchar DB, McCrory DC. Comparison and meta-analysis of randomized trials of endarterectomy for symptomatic carotid artery stenosis. Neurology. 1995;45:1965-1970.

11. Silver FL, Mackey A, Clark WM, et al. CREST Investigators. Safety of stenting and endarterectomy by symptomatic status in the Carotid Revascularization Endarterectomy Versus Stenting Trial (CREST). Stroke. 2011 Mar; 42 (3): 675-680.

12. Мазур С.Г., Костюк М.Р. Ультразвукове дуплексне сканування у виявленні стенозів високого ступеня сонних артерій та контролю ефективності їх оперативної корекції методом стентування.- Променева діагностика, променева терапія.-2006.-№4.-С18-24 


\title{
PЕЗЮМЕ
}

\section{ОЦЕНКА ЭФФЕКТИВНОСТИ ОПЕРАТИВНОГО ВМЕШАТЕЛЬСТВА ПРИ СТЕНОТИЧЕСКИХ ПОРАЖЕНИЯХ СОННЫХ АРТЕРИЙ ВЫСОКОЙ СТЕПЕНИ С ПОМОЩЫЮ МЕТОДА УЛЬТРАЗВУКОВОГО ДУПЛЕКСНОГО СКАНИРОВАНИЯ}

\author{
Мазур С.Г. ${ }^{1}$, Костюк М.Р. ${ }^{2}$, Дыкан И.Н. ${ }^{1}$, Кузнецов В.В. ${ }^{3}$

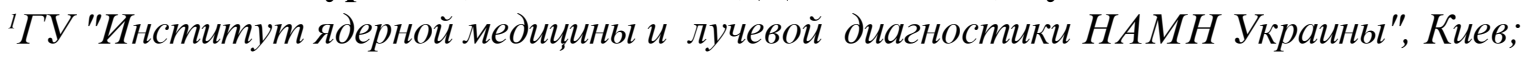 \\ ${ }^{2} Г У "$ "Институт нейрохирургии им.акад.А.П.Ромоданова НАМН Украины", Киев;

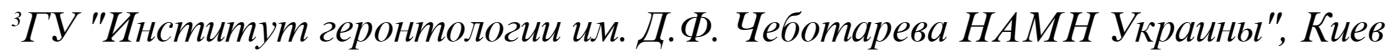

Цель работы: Динамическая оценка изменений состояния проходимости сонных артерий и показателей церебральной гемодинамики с помощью метода ультразвукового дуплексного сканирования после оперативной коррекции стенозов сонных артерий высокой степени.

Материалы и методы. Обследовано 62 пациента со стенозами сонных артерий высокой степени в возрасте от 43 до 84 лет, которым в 2003-2011 годах была выполнена операция каротидной ангиопластики и стентирования (КАС), 5 из них - в сочетании с каротидной эндартерэктомией (КЭА). Ультразвуковое исследование по установленному протоколу проводилось за 1 неделю перед операцией, на протяжении 1 недели и через 6-8 мес после нее.

Характер атеросклеротического поражения, степень выражености стеноза изучались с помощью ультразвукового дуплексного сканирования и церебральной ангиографии; определялись линейные и объемные скорости кровотока, рассчитывался показатель общего церебрального объемного кровотока , каротидно-каротидный индекс.

Результаты исследования. У больных с окклюзионно-стенотическими поражениями сонных артерий, которые требуют хирургической коррекции, определяются значительные нарушения гемодинамических показателей (появляется стенотический кровоток, возрастает величина каротидно-каротидного индекса). Оперативные методы лечения (КАС, при необходимости - в сочетании с КЭА) улучшают гемодинамические показатели прооперированных больных: восстанавливают проходимость артерии в участке поражения, устраняют стенотическое ускорение кровотока, нормализуют величину каротидно-каротидного индекса.

Ультразвуковое дуплексное сканирование имеет высокую точность и информативность в диагностике стенотических поражений сонных артерий, оценке состояния стента и проходимости внутренней сонной артерии (BCA) после операции, что отражает эффективность оперативного вмешательства. У больных с сочетанным стенотическим поражением обеих ВСА (стеноз высокой степени + окклюзия контралатеральной ВСА) после коррекции стеноза отмечается характерная положительная динамика изменений кровотока в каротидном и вертебро-базилярном басейнах.

Ключевые слова: каротидная артерия, дуплексное сканирование, каротидный стеноз. 


\title{
XÜLASə
}

\section{YUXU ARTERIYALARININ YÜKSӘK DӘRӘCӘLI STENOTIK ZODӘLONMOSİ ZAMANI OPERATIV MÜDAXILONIN EFFEKTIVLIYININ ULTRASOS DUPLEKS SKANLAŞDIRMA METODUNUN KÖMOKLIYII İLO QIYYMOTLONDIRİLMOSI}

\author{
Mazur S.Q. ${ }^{1}$, Kostyuk M.R. ${ }^{2}$, Dikan I.N. ${ }^{1}$, Kuznetsov V.V. ${ }^{3}$ \\ ${ }^{I} N \ddot{u} v$ ə tababəti və şüa diaqnostika institutu, Kiyev, Ukrayna; \\ ${ }^{2}$ Akademik A.P.Romodanov adına neyrocorrahiyy institutu, Kiyev, Ukrayna; \\ ${ }^{3}$ D.F.Çebotarev adina herontologiya institutu, Kiyev, Ukrayna
}

Tədqiqatın məqsədi yuxu arteriyalarının yüksək dərəcəli stenozunun cərrahi korreksiyasından sonra ultrasəs dupleks skanlaşdırma metodu ilə yuxu arteriyalarının keçiriciliyinin vəziyyətdə dəyişikliklərin və serebral hemodinamika göstəricilərinin dinamik qiymətləndirilməsi olmuşdur.

Material və metodlar. 2003-2011-ci illərdə karotid angioplastika və stentləmə (KAS) və 5 nəfərdə müştərək olaraq karotid endarterektomiya (KEA) əməliyyatları aparılmış 62 yuxu arteriyasının yüksək dərəcəli stenozu olan xəstə müayinə olunmuşdur. Xəstələrin yaşı 43-84 arası olmuşdur. Qeyd edilmiş protokola uyğun ultrasəs müayinəsi əməliyyatdan 1 həftə əvvəl, əməliyyatdan sonrak1 1 həftə ərzində və 6-8 ay sonra aparılmışdır. Aterosklerotik zədələnmənin xarakteri, stenozun qabarıqlıq dərəcəsi ultrasəs dupleks skanlaşdırma və serebral angioqrafiya ilə öyrənilmişdir; qan axımının xətti və həcmli sürəti təyin edilmiş, ümumi serebral həcmli qan axımı, karotid-karotid indeks qiymətləndirilmişdir.

Tədqiqatın nəticələri. Yuxu arteriyalarının cərrahi korreksiya tələb edən okklüzion-stenotik zədələnmələri olan xəstələrdə hemodinamik göstəricilərin əhəmiyyətli pozulması qeyd edilir (stenotik qan axımı yaranır, karotid-karotid indeksin qiyməti artır). Cərrahi müalicə metodları əməliyyat olunmuş xəstələrdə hemodinamik göstəriciləri yaxşılaşdırır: zədələnmə nahiyyəsindəki keçiriciliyi bərpa edir, qan axımının stenotik sürətlənməsini ləğv edir, karotid-karotid indeksin göstəricilərini normaya salır.

Ultrasəs dupleks skanlaşdırma yuxu arteriyalarının stenotik zədələnmələrinin diaqnostikası, əməliyyatdan sonra daxili yuxu arteriyasının (DYX) keçiriciliyinin və stentin vəziyyətinin qiymətləndirilməsi zamanı yüksək dəqiqliyə və informativliyə malikdir ki, bu da cərrahi müdaxilənin effektivliyini özündə əks etdirir. Hər iki daxili yuxu arteriyasının müştərək stenotik zədələnməsi (yüksək dərəcəli stenoz+kontralateral DYA-nın okklüziyası) olan xəstələrdə stenozun korreksiyasından sonra karotid və vertebro-bazilyar hövzələrdə qan axımının dəyişməsinin xarakter müsbət dinamikası qeyd edilir.

Açar sözlər: karotid arteriya, dupleks skanlaşdırma, karotid stenoz.

Redaksiyaya daxil olub: 18.03.2014

Çapa tövsiyə olunub: 02.04.2014

Rayçi: t.e.d., R.L.Hasənov 